\title{
PENGARUH KETERLIBATAN KERJA DAN STRES TERHADAP KINERJA GURU SMK SWASTA KECAMATAN MATRAMAN JAKARTA TIMUR
}

\author{
Ahmad Fathurrohman \\ Manajemen Pendidikan, Universitas Negeri Jakarta \\ Email : ahmad.fathurrohman@yahoo.com
}

\begin{abstract}
Abstrak
Penelitian ini bertujuan untuk mengetahui pengaruh dari (1) keterlibatan kerja, (2) stres, (3) kinerja guru-guru yang bekerja di SMK Swasta Kecamatan Matraman Jakarta Timur. Metode yang digunakan dalam penelitian ini adalah metode penelitian survey dengan pendekatan kuantitatif-kausal dengan menggunakan analisis jalur. Survey dilakukan sejak April sampai Juni 2018 dengan melibatkan 150 orang guru di suatu Kecamatan sebagai sampel yang ditentukan secara acak. Temuan dalam penelitan ini menunjukkan: Pertama, terdapat pengaruh langsung keterlibatan kerja terhadap kinerja. Kedua, terdapat pengaruh langsung negatif stres terhadap kinerja. Ketiga, terhadap pengaruh langsung negatif keterlibatan kerja terhadap stres.
\end{abstract}

Kata kunci : Keterlibatan kerja, Stres, dan Kinerja

\begin{abstract}
This research aims to show the effects of (1) job involvement, (2) stress, (3) the performance of teachers working in Private Vocational Schools (SMK) in Matraman subdistrict, East Jakarta. The method used in the research is a survey research method with a quantitative-causal approach using path analysis. The survey was conducted from April to June 2018 by taking randomly-selected samples consisting of 150 teachers in a subdistrict. The findings in this research show: First, there is a direct effect of job involvement on performance. Second, there is a direct negative effect of stress on performance. Third, there is a negative direct effect of job involvement on stress.
\end{abstract}

Keywords: Job involvement, stress and performance.

\section{PENDAHULUAN}

Pendidikan merupakan upaya strategis yang dilakukan dalam upaya meningkatkan sumber daya manusia (SDM) dalam hal pengetahuan (knowledge), keterampilan (skill), dan sikap (atitude). Melalui pendidikan, diharapkan dapat membangun SDM berkualitas yang kelak mampu membangun bangsa, karena pendidikan memegang peran utama dalam upaya mengangkat harkat dan martabat suatu bangsa.

Guru merupakan salah satu komponen utama yang mendukung peningkatan sumber daya manusia melalui pendidikan. Dalam Undang-Undang Guru dan Dosen Tahun Nomor 14 Tahun 2005 pasal 1 ayat (1), guru adalah pendidik profesional dengan tugas utama mendidik, mengajar, membimbing, mengarahkan, melatih, menilai dan mengevaluasi peserta didik pada pendidikan anak usia dini jalur pendidikan formal, pendidikan dasar, dan pendidikan menengah.

Kinerja guru merupakan penentu tinggi rendahnya kualitas pendidikan. Pendidikan dinyatakan berkualitas tinggi apabila guru bekerja mengacu pada visi, misi, tujuan, sasaran, dan target pendidikan yang disusun untuk menjawab berbagai perubahan dengan menggerakkan seluruh potensi sumber daya yang ada dalam lembaga pendidikan.

Tingginya kinerja guru dapat dibuktikan dengan kewenangan dan tanggungjawab 
kerja, perencanaan pembelajaran, pelaksanaan pembelajaran dan evaluasi program di sekolah, pengelolaan kurikulum, pengelolaan ketenagaan, pengelolaan peralatan dan perlengkapan, pengelolaan keuangan, pelayanan siswa, dan hubungan sekolah terhadap masyarakat.

Dalam suatu sekolah keterlibatan kerja guru juga memiliki peran yang sangat besar. Karena keterlibatan kerja berpengaruh terhadap kinerja guru, tingkat keterlibatan kerja yang tinggi berperan dalam membentuk kinerja, meningkatkan kualitas dan kuantitas hasil kerja, dan efisiensi kerja yang tinggi. Selain itu dalam keterlibatan kerja, para guru juga harus memiliki pemahaman yang mendalam tentang tujuan sekolah serta mengetahui rencana yang spesifik dalam mencapai tujuan.

Beratnya tuntutan tugas seseorang guru menyebabkan guru sering mengalami rasa bosan, jenuh dan juga mengakibatkan stres. Guru akan cenderung mengalami stres apabila kurang mampu beradaptasi keinginan dengan kenyataan yang ada, baik kenyataan yang ada di dalam maupun di luar dirinya. Segala macam bentuk stres, pada dasarnya disebabkan oleh kurang mengertinya manusia akan keterbatasannya sendiri. Ketidak mampuan untuk melawan keterbatasan inilah yang akan menimbulkan frustasi, konflik, gelisah dan rasa bersalah. Dari uraian di atas maka peneliti tertarik untuk meneliti tentang "Pengaruh Keterlibatan Kerja dan Stres Terhadap Kinerja Guru Pada SMK Swasta Kecamatan Matraman Jakarta Timur"

Pendapat yang dikemukakan oleh Schermerhorn, Hunt, Osborn dan Uhl-Bein [1] Kinerja adalah kualitas dan kuantitas pekerjaan yang dihasilkan. Gibson, Ivancevich, Donnely, dan Konopaske [2]
Kinerja adalah hasil dari pekerjaan yang berkaitan dengan tujuan organisasi seperti kualitas, efisiensi dan kriteria efektivitas kerja lainnya. Borman, Ilgen dan Klimoski [3] Kinerja adalah nilai total yang diharapkan organisasi yang dipisahkan oleh perilaku dari individu dalam mengerjakan pekerjaannya selama waktu yang sudah ditentukan. Amstrong [4] Kinerja diukur dalam beberapa dimensi dari segi kompetensi yang dibutuhkan untuk mencapai tingkat sasaran kinerja dalam pekerjaan tertentu atau pada tingkat tertentu dalam organisasi.

George dan Jones [5] Kinerja adalah evaluasi hasil perilaku seseorang: menentukan seberapa baik atau buruk seseorang telah menyelesaikan tugas atau melakukan pekerjaannya. Menurut Locke [6] Kinerja dikonseptualisasikan sebagian berasal dari proses perencanaan di tempat kerja. Secara historis, kinerja didefinisikan oleh serangkaian pernyataan tugas yang berasal dari pekerjaan yang di deskripsikan. Williams [7] Kinerja adalah seberapa baik seseorang melaksanakan kebutuhan pekerjaan tersebut. Pengertian kinerja Kinerja adalah seperangkat dari nilai perilaku pegawai yang berkontribusi secara positif atau negatif untuk mencapai tujuan organisasi.

Berdasarkan uraian konsep di atas maka dapat disintesiskan kinerja adalah perilaku seseorang untuk menyelesaikan pekerjaan yang berhubungan dengan organisasi dengan indikator yaitu: usaha dalam bekerja, kualitas kerja, keberhasilan melaksanan tugas, dan pencapaian tujuan.

Noe, Hollenbeck, Gerhart dan Wright [8] Keterlibatan kerja adalah sejauh mana orang mengidentifikasi diri mereka dengan pekerjaan rnereka. Orang-orang yang tidak terlibat dengan pekerjaan mereka menganggap pekerjaan mereka merupakan 
aspek tidak penting dari kehidupan mereka. Ones, Anderson, Viswesvaran dan Sinangil [9] . Keterlibatan kerja diartikan sebagai tingkatan pegawai yang secara kognitif menyibukkan diri, terlibat dalam dan barkaitan dengan pekerjaan orang tersebut. Blau and Boal [10]. Keterlibatan kerja didefinisikan sebagai sejauh mana seorang individu mengidentifikasi secara psikologis dengan pekerjaannya.

Milward [11] Keterlibatan kerja didefinisikan dalam literatur sebagai sejauh mana seseorang mengidentifikasi secara psikologis dengan pekerjaannya, karakteristik yang relatif stabil berdasarkan orientasi nilai pribadi. Srivastava [12] Keterlibatan kerja dapat didefinisikan sebagai keadaan kognitif umum dengan pekerjaan identifkasi psikologis sejauh kerja dianggap memiliki potensi untuk memenuhi kebutuhan seseorang menonjol dan harapan.

Lawler and Hail [12] Keterlibatan kerja dalam hal identifikasi psikologis dengan pekerjaan atau pentingnya pekerjaan terhadap total citra diri seseorang. Blau and Boal [12] Keterlibatan kerja adalah sejauh mana karyawan membenamkan diri dalam pekerjaan mereka, menginvestasikan waktu dan energi di dalamnya dan melihat pekeijaan sebagai bagian pusat dari kehidupan mereka secara keseluruhan.

Berdasarkan deskripsi konsep di atas dapat disintesiskan bahwa keterlibatan kerja adalah tingkatan bagi setiap seseorang untuk melibatkan diri mereka sendiri dalam pekerjaannya, dengan indikator berpartisipasi aktif, pengambilan keputusan, memihak pekerjaan, menyumbangkan ide dan menaati peraturan.

Colquitt, Lepine dan Wesson [13]. Stres adalah respon psikologis terhadap tuntutan yang ada. McShane dan Glinow [14] Stres adalah suatu kondisi fisiologis dan psikologis yang mempersiapkan kita untuk beradaptasi dengan permusahan dengan teman atau kondisi lingkungan yang berbahaya. Mosley dan Pietri [15] Stres sebagai berikut. Stres adalah setiap stimulus eksternal yang menyebabkan seseorang yang mengancam kesejahteraannya terhadap psikologis atau fisik.

Sinding dan Waldstrom [16] Stres adalah sebuah respon adaptif dari setiap individu yang dipengaruhi oleh karakter dari setiap pribadi atau proses psikologi yang merupakan konsekuensi dari setiap tindakan atau situasi, keadaan dari luar sehingga menyebabkan adanya tuntutan psikologis maupun fisik yang khusus pada seseorang. Luthans [17] Stres didefinisikan sebagai respons adaptif terhadap situasi eksternal yang menghasilkan penyimpangan fisik, psikologis, dan atau perilaku pada anggota lain.

Menurut Ivancevich [17] Stres adalah sebagai interaksi individu dengan lingkungan, kemudian mereka mendefinisikan kerja adalah sebagai respons adatif yang dihubungkan oleh perbedaan individu atau proses psikologis yang merupakan konsekuensi tindakan, situasi, atau kejadian eksternal lingkungan yang menempatkan tuntutan psikologis atau fisik secara berlebihan pada seseorang.

Dengan demikian, dari deskripsi konsep di atas dapat disintesiskan stres kerja adalah kondisi seseorang terhadap tanggapan pada tekanan baik dari dalam diri maupun dari lingkungannya, dengan indikator yaitu: fisik, perilaku, dan kepribadian.

\section{METODE}

Penelitian ini menggunakan pendekatan kuantitatif, metode survey dan teknik 
analisis jalur. Variabel pada analisis jalur terdiri dari variabel eksogen dan variabel endogen. Penelitian ini menggunakan metode field research dengan menggunakan pendekatan analisis jalur, karena metode ini bersifat kuantitatif maka pengolahan data menggunakan statistik. Populasi terjangkau penelitian ini adalah guru SMK Swasta Kecamatan Matraman Jakarta Timur yang berjumlah 239 guru. Dan perhitungan dengan menggunakan slovin, maka di peroleh jumlah sampel sebanyak 150 guru yang dijadikan sampel frame dalam penelitian ini. Pengumpulan data digunakan untuk penelitian ini adalah statistika deskriptif dan statistika inferensial.

\section{HASIL DAN PEMBAHASAN Pengaruh Keterlibatan Kerja terhadap Kinerja}

Dari hasil pengujian hipotesis pertama dapat disimpulkan bahwa terdapat pengaruh langsung positif keterlibatan kerja terhadap kinerja dengan nilai koefisien korelasi sebesar 0,600 dan nilai koefisien jalur sebesar 0,430. Ini memberikan makna keterlibatan kerja berpengaruh langsung terhadap kinerja.

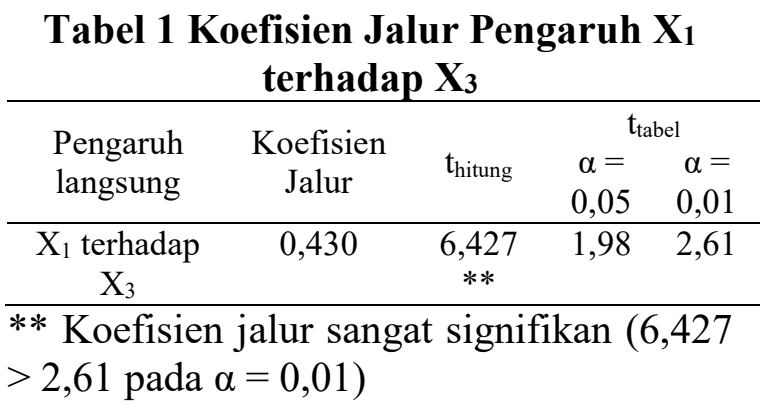

Dari hasil pengujian hipotesis pertama dapat disimpulkan bahwa terdapat pengaruh langsung positif keterlibatan kerja terhadap kinerja dengan nilai koefisien korelasi sebesar 0,600 dan nilai koefisien jalur sebesar 0,430. Ini memberikan makna keterlibatan kerja berpengaruh langsung terhadap kinerja.

Hasil penelitian ini senada dengan pendapat beberapa ahli di antaranya adalah Stephen P Robbins dan Timohty A Judge [18]. Dalam hal ini keterlibatan kerja diartikan sebagai tingkatan seseorang untuk mengidentifikasikan kondisi psikologis seseorang terhadap pekerjaannya dan sebagai pertimbangan dalam mengukur performa kerja mereka pada tingkat tertentu.

Cungtai [19] berpendapat bahwa keterlibatan kerja dibagi menjadi dua pendekatan, yaitu. Pendekatan pertama di pandang sebagai variabel perbedaan individu. Keterlibatan kerja diyakini terjadi ketika kepemilikan kebutuhan tertentu, nilai-nilai atau karakteristik pribadi mempengaruhi individu untuk menjadi lebih atau kurang terlibat dalam pekerjaan mereka. Pendekatan kedua memandang keterlibatan kerja sebagai respon terhadap karakteristik situasi kerja tertentu. Dengan kata lain situasi yang mempengaruhi sejauh mana seorang individu menjadi terlibat dalam pekerjaannya.

\section{Pengaruh Stres terhadap Kinerja}

Dari hasil pengujian hipotesis kedua dapat disimpukan bahwa terdapat pengaruh langsung negatif stres terhadap kinerja dengan nilai koefisien korelasi sebesar 0,572 dan nilai koefisien jalur sebesar 0,378. Ini memberikan makna stres berpengaruh langsung terhadap kinerja.

Tabel 2 Koefisien Jalur Pengaruh $\mathrm{X}_{2}$ terhadap $\mathrm{X}_{3}$

\begin{tabular}{lllll}
\hline $\begin{array}{l}\text { Pengaruh } \\
\text { langsung }\end{array}$ & $\begin{array}{l}\text { Koefisien } \\
\text { Jalur }\end{array}$ & $-\mathrm{t}_{\text {hitung }}$ & $\begin{array}{l}-\mathrm{t}_{\text {tabel }} \\
\alpha=\end{array}$ \\
0,05 & 0,01 \\
\hline $\mathrm{X}_{2}$ terhadap & $-0,378$ & - & - & - \\
$\mathrm{X}_{3}$ & & $5,652 * *$ & 1,98 & 2,61 \\
\hline$* *$ & Koefisien jalur & sangat & signifikan $(-$ \\
$5,652<-2,61$ pada $\alpha=0,01)$
\end{tabular}


Hasil penelitian ini senada dengan pendapat beberapa ahli di antaranya adalah Cohen [20] diungkapkan bahwa. Pendapat ini dapat diartikan bahwa, pada setiap tahap kehidupan, stres dapat menjadi faktor yang mempengaruhi kinerja.

Dikemukakan oleh Hellriegel dan Slocum [21]. Pengaruh dari stres kerja memiliki implikasi penting bagi perilaku organisasi dan efektivitas organisasi. Beberapa pengaruh ini yaitu pada kesehatan, kinerja, dan termasuk kelelahan kerja. Dari uraian di atas dapat diduga, stres kerja berpengaruh negatif terhadap kinerja.

Bernadin [22] Stres adalah membuat pekerja sakit, meningkatkan potensi terhadap kekerasan di tempat kerja, dan mempengaruhi tingkat produktivitas dan kecelakaan. Gibson, Donnelly, Ivancevich, dan Konopaske [2] Stres sebagai respon adaptif yang dimediasi oleh perbedaan individu, yang merupakan konsekuensi dari setiap tindakan, situasi, atau peristiwa yang menempatkan tuntutan khusus pada seseorang.

Menurut Ivancevich, Mattenson didalam Fred Luthans [17] mendefinisikan stres sebagai berikut; pengertian stres dalam bekerja, Stres adalah sebagai interaksi individu dengan lingkungan, kemudian mereka mendefinisikan kerja adalah sebagai respons adatif yang dihubungkan oleh perbedaan individu atau proses psikologis yang merupakan konsekuensi tindakan, situasi, atau kejadian eksternal lingkungan yang menempatkan tuntutan psikologis atau fisik secara berlebihan pada seseorang.

Selanjutnya James L. Gibson, James H. Donnelly, Jr, John M. Ivancevich, Robert Konopaske [2] mengatakan. Dalam konteks definisi stres, penting untuk memahami bahwa stres adalah hasil dari berurusan dengan sesuatu yang menempatkan tuntutan khusus kami. Khusus di sini berarti biasa, fisik atau psikologis mengancam atau di luar set kami biasa pengalaman. Memulai tugas pekerjaan baru di negara lain, mengubah bos, hilang pesawat, memiliki sistem komputer gagal di tengah proyek penting, mengadakan pertemuan evaluasi kinerja.

Menurut pendapat yang diungkapkan oleh Cohen [20] diungkapkan bahwa, Pendapat ini dapat diartikan bahwa, pada setiap tahap kehidupan, stres dapat menjadi faktor yang mempengaruhi kinerja.

\section{Pengaruh Keterlibatan Kerja terhadap Stres}

Dari hasil pengujian hipotesis ketiga dapat disimpulkan bahwa terdapat pengaruh langsung negatif keterlibatan kerja terhadap stres dengan nilai koefisien korelasi sebesar -0,449 dan nilai koefisien jalur sebesar -0,449. Ini memberikan makna keterlibatan kerja berpengaruh langsung terhadap stres.

Tabel 3 Koefisien Jalur Pengaruh $X_{1}$ terhadap $\mathrm{X}_{2}$

\begin{tabular}{llccl}
\hline $\begin{array}{l}\text { Pengaruh } \\
\text { langsung }\end{array}$ & $\begin{array}{l}\text { Koefisien } \\
\text { Jalur }\end{array}$ & - $\mathrm{t}_{\text {hitung }}$ & $\begin{array}{l}-\mathrm{t}_{\text {tabel }} \\
\alpha= \\
0,05\end{array}$ & $\begin{array}{l}\alpha=01 \\
0,0\end{array}$ \\
\hline $\mathrm{X}_{1}$ terhadap & $-0,449$ & $-5,920$ & - & - \\
$\mathrm{X}_{2}$ & & $* *$ & 1,98 & 2,61 \\
\hline$* *$ & Koefisien jalur & sangat & signifikan & $(-$ \\
$5,920>-2,61$ pada $\alpha=0,01)$
\end{tabular}

Hasil penelitian ini senada dengan pendapat beberapa ahli di antaranya adalah Rae andre [23] berpendapat bahwa: Keterlibatan kerja adalah keyakinan bahwa ada hubungan antara kinerja individu dalam pekerjaannya dan harga dirinya. Perusahaan atau organisasi lebih memilih untuk melihat karyawan mereka secara psikologis terlibat dengan pekerjaan mereka karena keterlibatan tersebut terkait dengan ketidakhadiran rendah dan 
berkurangnya pemberhentian seseorang. Di sisi lain, ketererlibatan yang tinggi dengan satu jenis pekerjaan dapat memperburuk reaksi individu menjadi stres yang mengancam performanya. meningkatkan kemungkinan penyakit dan penggunaan alkohol.

Selain itu Kreitner dan Kinicki, [24] juga menjelaskan bahwa stres kerja muncul dari empat macam faktor yang dibedakan kedalam empat tingkat, yakni pertama merupakan tingkat individual seperti tuntutan pekerjaan, konflik peran, kelebihan dan kekurangan beban kerja, yang kedua merupakan tingkat kelompok, seperti perilaku manajerial, perbedaan status, serta adanya konflik didalam kelompok, yang ketiga adalah tingkat organisasi yang meliputi kebudayaan, struktur, teknologi, serta adaptasi dengan kondisi kerja, yang keempat merupakan tingkat ekstraorganisasional seperti keluarga, ekonomi, serta kondisi tempat kerja yang kurang nyaman.

Ouyang [25] Keterlibatan kerja merupakan derajat individu berpartisipasi aktif dalam pekerjaannya, memposisikan pekerjaan sebagai pusat perhatian hidup yang penting bagi harga diri. Akan tetapi dengan munculnya tekanan serta kurangnya komunikasi antar seseorang maupun dengan atasan akan turut mempengaruhi keterlibatan seseorang. Selain itu kondisi pekerjaan yang tidak stabil juga turut mempengaruhi keterlibatan kerja seseorang, seperti yang dijelaskan dalam sebuah penelitian bahwa pekerjaan yang tidak stabil memiliki pengaruh negatif pada keterlibatan kerja dan memiliki pengaruh positif terhadap stres kerja.

Sedangkan menurut Fred Niederman and Thomas W. Ferralt [26] Keterlibatan kerja akan mempengaruhi, bagaimana informasi sistem yang profesional menanggapi kualitas dari komponen kehidupan pekerjaan, seperti pengalaman pekerjaan, karir, harapan, tingkah laku, dan stres.

Ringkasan model analisis jalur dapat terlihat pada gambar 1 sebagai berikut :

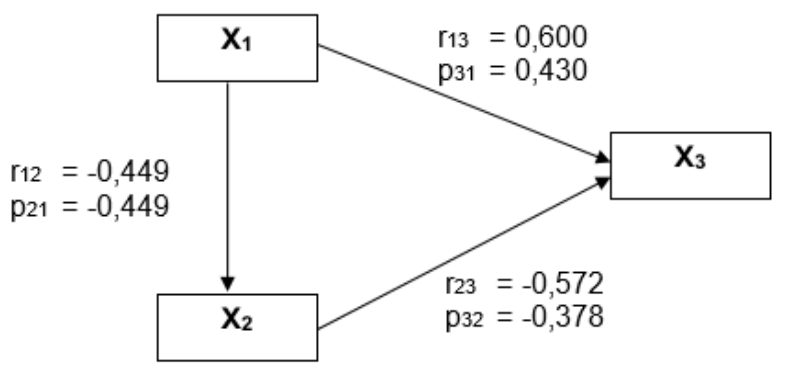

Gambar 1. Model Empiris Antar Variabel

\section{SIMPULAN}

Berdasarkan hasil data penelitian dan hasil analisis data penelitian yang telah dibahas dengan semua persyaratan analisis data yang meliputi uji homogenitas, uji linieritas serta keberartian regresi telah dipenuhi, maka dapat diambil beberapa kesimpulan sebagai berikut : (1) Keterlibatan kerja berpengaruh langsung positif terhadap kinerja. Artinya keseusaian keterlibatan kerja yang dimiliki guru mengakibatkan peningkatan kinerja guru SMK Swasta Kecamatan Matraman Jakarta Timur. (2) Stres berpengaruh langsung negatif terhadap kinerja. Artinya peningkatan stres guru mengakibatkan penurunan kinerja guru SMK Swasta Kecamatan Matraman Jakarta Timur. (3) Keterlibatan kerja berpengaruh langsung negatif terhadap stres. Artinya rendahnya keterlibatan kerja yang dimiliki guru akan mengakibatkan penurunan kinerja guru SMK Swasta Kecamatan Matraman Jakarta Timur.

\section{UCAPAN TERIMA KASIH}

Puji syukur kehadirat Allah SWT atas segala Karunia-Nya sehingga artikel ini dapat terselesaikan. Oleh karena itu, 
penyusun mengucapkan terima kasih yang tulus kepada semua pihak yang telah membantu meyelesaikan artikel ini, khususnya Dosen pembimbing, Kepala Sekolah SMK Swasta Kecamatan Matraman Jakarta Timur, serta para guru yang telah bersedia menjadi responden penelitian. Semoga Allah SWT membalas dengan pahala yang setimpal. Aamiin.

\section{DAFTAR PUSTAKA}

[1] Schermerhorn, John R., James G. Hunt, Richard N. Osborn, Mary UhlBein. "Organizational Behavior 11th Edition." USA: Wiley, 2010.

[2] Gibson, James L., John M. Ivancevich, James H. Donnely, Robert Konopaske. "Organizations Behavior Structure." New York: Mc Graw Hill, 2009.

[3] Borman, Walter C., Daniel R. Ilgen, Richard J. Klimoski. "Handbook of Psychology." New Jersey: John Willey and Son, 2003.

[4] Armstrong Michael. "A Handbook Of Human Resource Management Practice 7th Edition". London: Kogan Page, 1999.

[5] George, Jennifer M., and Gareth R. Jones. "Understanding and Managing Organizational Behavior, 6th Edition." New Jersey: Pearson Education, 2012.

[6] Locke Edwin A., "Handbook of principles of organizational behavior." United Kingdom: John Wiley \& Sons, 2009.

[7] Williams Chuck. "Management 6 edition." South Western: Cengage Learning, 2011.

[8] Noe, Raymond A., John R. Hollenbeck, Barry Gerhart, Patrick M. Wright. "Fundamentals of Human Resource Management." New York McGraw-Hill/Irwin, 2016
[9] Ones, Deniz S., Neil Anderson. "Chockalingam Viswesvaran and Handan Kepir Sinangil, Industrial, Work and Organizational Psychology." Sage, 2017.

[10] Cheiladurai Packianathan, Shannon Kerwin. "Human Resource Management in Sport and Recreation." USA: 2nd Ed, 2017.

[11] Millward Lynne. "Understanding Occupational \& Organizational Psychology." SAGE Publicatons, 2005.

[12] Srivastava, S.K. "Organizational Behaviour and Management." Sorup and Sons, 2005.

[13] Colquitt, Jason A., Jeffery A. Lepine, Michael J. Wesson. "Organizational Behavior: Improving Performance and Commitment in the Workplace." New York: McGraw-Hill/Irwin, 2015.

[14] McShane, Steven L., Mary Ann Von Glinow, "Organizational behavior Emerging Knowledge and practice for the real word 5th Edition." McGraw-Hill, 2010.

[15] Mosley Jr, Donald C., Donald C. Mosley Sr, Paul H. Pietri. "Supervisory Management." Cengage Lerning, 2008.

[16] Sinding, Knud and Christian Waldstrom "Organizational Behavior, Ninth Edition." New York: McGraw-Hill, 2014.

[17] Luthans, Fred, Brett C. Luthans, Kyle W. Luthans. "Organizational Behavior, An Evidence-Based Approach 13th." US of America; 2015.

[18] Christiansen, Bryan and Harish C. Chandan. "Organizational Culture and Diversity in the Modern Workforce." US of America; IGI Global, 2017.

[19] Chungtai, Aamir Ali., "Impact of Job Involvement on In Organizational 
Citizenship Behaviour." Ireland Dublin City University, 2008.

[20] Cohen, Allan R., et. al., "Effective Behavior in Organizations, Cases, Concepts, and Student Experiences, Seventh Edition." New York: McGraw-Hill, Irwin, 2010.

[21] Hellriegel Don, John W. Slocum, Jr. "Organizational Behavior." Tenth Edition. Canada: Thomson, 2004.

[22] Bernadin, H. Jhon. "Human Resource Management." New York: McGraw-Hill, 2007.

[23] Andre Raa, "Organizational Behavior, An introduction to your life in organizations" New Jersey: Pearson Prentice Hall, 2008.

[24] Kreitner. R, Kinicki. A. "Perilaku Organisasi." edisi 5 Salemba, 2005

[25] Ouyang Y. "The Mediating Effect Of Job Stress \& Job Involvement Under Job Instability : Banking Service Personnel Of Taiwan As An Example." Journal of Money, Investement and Banking. Issue II, 2009.

[26] Niederman, Fred and Thomas W. Ferralt, "IT Workers; Human Capital Issues In A Knowledge-Based Environment." 2009 